\title{
Apoptomirs: small molecules have gained the license to kill
}

\author{
Andrea Vecchione ${ }^{1,2}$ and Carlo M Croce ${ }^{1}$
}

\author{
${ }^{1}$ Human Cancer Genetics Program, Comprehensive Cancer Center, The Ohio State University, Columbus, OH, USA \\ 2Division of Pathology, University of Rome 'La Sapienza', Ospedale Sant'Andrea, Rome, Italy \\ (Correspondence should be addressed to A Vecchione, Human Cancer Genetics Program, Division of Pathology, Comprehensive \\ Cancer Center, The Ohio State University, 400 West 12th Avenue, Columbus, OH 43216, USA; Email: andrea.vecchione@ uniroma1.it)
}

\begin{abstract}
Apoptosis is a tightly regulated form of cell death and represents an important process during normal development. In the past years, the scientific community has produced remarkable advances in our understanding of cancer biology, realizing that apoptosis and the genes that control it have a profound effect on the malignant phenotype. Recently, a new class of non-coding RNA genes, known as microRNA (miRNA or miR), have been demonstrated to play important roles in diverse biological processes, including development, cell differentiation, proliferation, and apoptosis. This suggests that other oncogenic mechanisms are needed to produce selective pressure to override apoptosis during multistage carcinogenesis. Intriguingly, since most cytotoxic anticancer agents induce apoptosis, it is possible that defects in apoptotic programs may contribute to treatment failure. Several studies strongly suggest a role for microRNAs in modulating sensitive/resistant phenotypes to cytotoxic therapy, calling for further investigation and validation of microRNA functions and targets in order to improve sensitivity to cancer treatments, thus ultimately improving prognosis and survival. Here, we review the current findings about microRNAs focusing on their involvement in the apoptotic process.
\end{abstract}

Endocrine-Related Cancer (2010) 17 F37-F50

\section{Introduction}

MicroRNAs (miRNAs or miRs) are non-protein coding genes thought to regulate the expression of up to $30 \%$ of human genes, either inhibiting mRNA translation or inducing its degradation (Lewis et al. 2005). Besides a crucial role in cellular differentiation and organism development (Kloosterman \& Plasterk 2006), miRs are frequently misregulated in human cancer (Lu et al. 2005, Volinia et al. 2006) and they can act as either potent oncogenes or tumor suppressor genes (Esquela-Kerscher \& Slack 2006).

In humans, miRs are expressed as long precursor RNAs transcribed by RNA polymerase II, which are known as primary miRs (pri-miRs) that are capped at

This paper is one of 6 papers that form part of a special Focus Section on microRNAs. The Guest Editors for this section were Professor Alfredo Fusco, Naples, Italy, and Professor Carlo M Croce, Columbus, OH, USA; they were not involved in the handling of this paper, on which they are listed as an author. the $5^{\prime}$-end and have a $3^{\prime}$-poly (A) tail (Lee et al. 2002, Cai et al. 2004).

Pri-miRs undergo a two-step maturation process to produce functional miRs. The first step occurs in the nucleus and is facilitated by Drosha, a cellular endonuclease, and the double-stranded RNA-binding domain protein DGCR8 (Lee et al. 2003, Han et al. 2004). Drosha cleaves both strands of the pri-miR in a staggered manner, producing a stem loop precursor molecule $\sim 70$ nucleotides in length known as a premiR (Lee et al. 2003, Kim 2005, Bushati \& Cohen 2007). These precursors are subsequently transported to the cytoplasm by an exportin-5-dependent mechanism (Yi et al. 2003), where they are cleaved by the DICER enzyme and by a double-stranded RNA-binding domain protein TRBP, resulting in $<17-24$ nt mature miRs (Ketting et al. 2001, Chendrimada et al. 2005), which associate with a RNA-induced silencing-like complex (RISC; Bushati \& Cohen 2007). The interaction of miR/RISC and its target mRNA results in gene regulation (Hammond et al. 2000). 
The expression patterns, function, and regulation of miRs are largely unknown, but emerging data and the frequent location of miRs at fragile sites, common breakpoints, regions of amplification, or loss of heterozygosity suggest that they may play significant roles in human carcinogenesis. Each miRs has a distinct capability to potentially regulate the expression of dozens of coding genes and thereby modulate several cellular pathways including those involved in proliferation, apoptosis, and stress response (Yanaihara et al. 2006).

Apoptosis is an evolutionary conserved process by which organisms remove cells that are superfluous, have outlived their usefulness, or are dangerous for the survival of the organism.

The apoptotic process can be executed intracellularly, which involves the release of a number of factors from mitochondria and can be activated by a diverse set of stressors (intrinsic pathway) or through transmembrane death receptors (DRs), which are activated when they are engaged by their cognate ligands (extrinsic pathway; Fig. 1).
The intrinsic apoptotic pathway hinges on the balance of activity between pro- and anti-apoptotic members of the BCL2 superfamily of proteins, which act to regulate the permeability of the mitochondrial membrane (Coultas \& Strasser 2003). The anti-apoptotic BCL2 proteins Bcl-2 and Bcl-xL act to prevent permeabilization of the mitochondrial outer membrane by inhibiting the action of the pro-apoptotic multidomain BCL2 proteins BAX (a cytosolic protein) and $\mathrm{BAK}$ (found in the mitochondrial membrane; Reed 1998). Overexpression of $\mathrm{Bcl}-2$ and $\mathrm{Bcl}-\mathrm{xL}$ is known to be associated with a number of human malignancies (Igney \& Krammer 2002, Bush \& Li 2003, Coultas \& Strasser 2003). Other pro-apoptotic BCL2 family members, including the BH3-only proteins PUMA and NOXA, act as cytosolic sensors of cell damage or stress (Karst \& Li 2007). The intrinsic pathway begins with cell stress triggering the active transcriptional up-regulation of specific members of the pro-apoptotic BCL2 protein family involved in the promotion of apoptosis, such as the $\mathrm{BH} 3$-only proteins PUMA and NOXA. These, in turn, activate the multi-domain

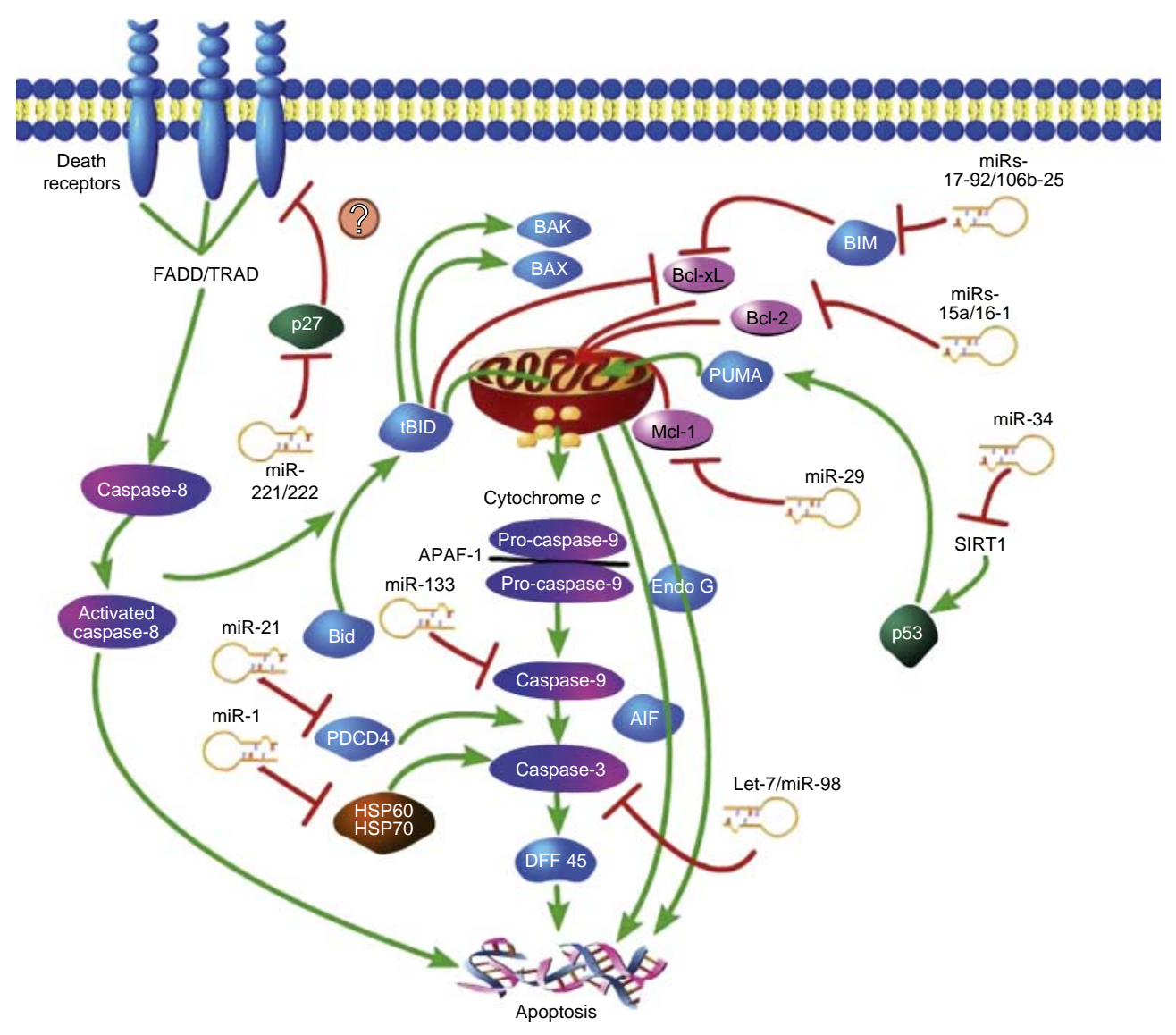

Figure 1 Representation of the role of miRs in apoptosis. Pro-apoptotic molecules are depicted in blue, and anti-apoptotic molecules are depicted in fuchsia. 
pro-apoptotic proteins $\mathrm{BAX}$ or $\mathrm{BAK}$, which move to the mitochondrial membrane and disrupt the function of the anti-apoptotic BCL2 proteins, thereby allowing permeabilization of the mitochondrial membrane (Henry-Mowatt et al. 2004). Cytochrome $c$ and the pro-apoptotic proteins SMAC/DIABLO are then able to leak from the intermembrane space of the mitochondria into the cytosol (Henry-Mowatt et al. 2004). Cytochrome $c$ binds the adaptor protein apoptotic protease-activating factor-1, forming a large multiprotein structure known as the apoptosome (Fig. 1). The apoptosome then recruits and activates caspase-9, which, in turn, activates the downstream effector caspases, including caspases-3, -6 , and -7 , leading to apoptosis. Under normal conditions, caspase activity is held in check by a protein family known as inhibitor of apoptosis proteins (IAPs), of which at least ten have been identified, including XIAP, cIAP1, cIAP2, ILP2, MLIAP, SURVIVIN, and BRUCE (Deveraux \& Reed 1999, Lavrik et al. 2005). IAPs are characterized by the presence of between one and three specific domains termed baculoviral repeats, which are directly involved in the caspase-inhibitory activity. While not directly involved in apoptotic signaling per se, some of these proteins prevent cell death by suppressing endogenous initiator and effector caspase activity. As part of the intrinsic apoptosis pathway, the SMAC/DIABLO protein released from the mitochondria promotes apoptosis by directly interacting with IAPs and disrupting their ability to inactivate the caspase enzymes (Srinivasula et al. 2000, Henry-Mowatt et al. 2004). Emerging evidence also suggests that IAPs may play a role in modulating cell division (Schimmer 2004). The IAPs survivin and cIAP1 are overexpressed in several malignancies.

The extrinsic pathway begins outside the cell through the activation of specific pro-apoptotic receptors on the cell surface by specific molecules known as pro-apoptotic ligands. These ligands include Apo2L/TRAIL (receptors DR4 and DR5) and CD95L/FasL (receptor CD95/Fas) (Ashkenazi 2002, Debatin \& Krammer 2004, Rowinsky 2005, Fulda \& Debatin 2006). Unlike the intrinsic pathway, the extrinsic pathway triggers apoptosis independently of the p53 protein (Rieger et al. 1998, Ravi et al. 2004).

Once activated by extracellular ligand binding, the intracellular domains of these receptors, known as the 'death domains', bind to the adaptor protein Fasassociated death domain (FADD), leading to the assembly of the death-inducing signaling complex, or DISC, and recruitment and assembly of initiator caspases-8 and -10 (Boldin et al. 1995, Chinnaiyan et al. 1995, Kischkel et al. 1995, Wang et al. 2001).
Caspases- 8 and -10 are stimulated and undergo selfprocessing, releasing active enzyme molecules into the cytosol, where they activate caspases-3, -6 , and -7 , thereby converging on the intrinsic pathway (Fig. 1).

\section{miRs and apoptosis}

The involvement of miRs in apoptosis was first reported in 2003 when miR-14 and bantam were shown to regulate cell death in Drosophila (Brennecke et al. 2003, Xu et al. 2003). Bantam, originally identified as a gene that causes overgrowth of wing and eye tissue (Hipfner et al. 2002), was demonstrated to be a miR and was shown to promote proliferation and inhibit apoptosis by targeting the pro-apoptotic gene hidl (Brennecke et al. 2003). miR-14, identified in a screen for genes that alter cell death in the Drosophila eye, was demonstrated to inhibit apoptosis by regulating the effector caspase Drice (Xu et al. 2003).

In the following, we will discuss several miRs that are reported to be involved in cell death (summarized in Table 1 and Fig. 1).

\section{miR-1/miR-133}

The miR-1 subfamily contains two distinct genes, miR 1-1 and miR 1-2, which are specifically expressed in cardiac and skeletal muscle precursor cells, being direct transcriptional targets of muscle differentiation regulators, including serum response factor $\mathrm{MyoD}$ and MEF2 (Zhao et al. 2005). Excess miR-1 in the developing heart leads to a decreased pool of proliferating ventricular cardiomyocytes.

miR-1 and miR-133 derive from the same miR polycistron and are transcribed together (Chen et al. 2006). Interestingly, they carry out distinct biologic functions: miR-1 promotes myogenesis by targeting histone deacetylase-4, a transcriptional repressor of muscle gene expression, while miR-133 enhances myoblast proliferation by repressing serum response factor.

In addition, miR-1 and miR-133 are involved in regulating cell fate in cardiomyocytes (Xu et al. 2007). miR-1 and miR-133 produce opposing effects on apoptosis induced by oxidative stress in $\mathrm{H} 9 \mathrm{c} 2$ rat ventricular cell, with miR-1 being pro-apoptotic and miR-133 being anti-apoptotic. Post-transcriptional repression of HSP60 and HSP70 by miR-1 and caspase- 9 by miR133 contributes significantly to their opposing actions.

Recently, it has been demonstrated that miR-1 exerts its pro-apoptotic effect by regulating Bcl-2 expression on both mRNA and proteins levels (Tang et al. 2009). 
Table $1 \mathrm{miRs}$ involved in apoptosis

\begin{tabular}{llll}
\hline miR & $\begin{array}{l}\text { Chromosome } \\
\text { location }\end{array}$ & Function & $\begin{array}{l}\text { Targets relevant } \\
\text { to apoptosis }\end{array}$ \\
\hline miR-1 & $20 q 13$ & Promotes myogenesis targeting HDAC4 & HSP60 \\
miR-133 & $18 q 11$ & ESP70 \\
Let-7/miR-98 & Xp11 & Development of Caenorhabditis elegans & Caspase-9 \\
miR-15a & $13 q 14$ & Regulates pancreatic regeneration & Caspase-3 \\
miR-16-1 & $13 q 14$ & Negatively regulates cell cycle progression and & BCL-2 \\
& & cell growth & BCL-2 \\
miR-21 & $17 q 23$ & Regulates pancreatic regeneration & PTEN TMP1 PDCD4 \\
miR-29 & $7 q 32$ & Unknown & Mcl-1 \\
miR-34a & $1 p 36$ & DNA methylation & SIRT1 CDK4 \\
miR-34b/c & $11 q 23$ & Regulation of cell cycle & CDK6 \\
miR-106b-25 & $7 q 22$ & Regulation of proliferation and & adhesion-independent cell growth \\
miR-17-92 & $17 q 31.3$ & Regulates E2F1 involved in TGF $\beta$ pathway & BIM \\
miR-221 & Xp11.3 & Regulation of erythropoiesis & p27 \\
miR-222 & Xp11.3 & Regulation of erythropoiesis & p27 \\
\hline
\end{tabular}

\section{Let-7/miR-98}

Let-7 was first identified in Caenorhabditis elegans and is one of the founding members of the miR family (Reinhart et al. 2000). The let-7 family consists of 11 very closely related genes (Pasquinelli et al. 2000). Let-7 is conserved in vertebrates and invertebrates; the expression increases after differentiation and in mature tissue but is barely detectable in the embryonic stage (Lee et al. 2005). This is due to the regulation of the processing of the let- 7 family of miRs by LIN28, a developmentally regulated RNA-binding protein, which is involved in miR processing and promotes the reprograming of human somatic cells into induced pluripotent stem cells (Yu et al. 2007). LIN28 selectively blocks the processing of pri-let-7 miRs in embryonic stem cells (ES) by specifically binding to conserved nucleotides in the loop region of the let-7 precursor and inhibiting the activity of Drosha and Dicer, thus having a central role in blocking miR-mediated differentiation in ES cells (Rybak et al. 2008, Viswanathan et al. 2008). These findings also establish a novel role for the miR precursor loop region in the regulated production of mature let-7 (Newman et al. 2008). These discoveries have started to reveal the intricate and complex web of regulatory networks through which miRs become part of the integrated mechanism of gene regulation that defines ES cell fate and behavior.

Previous studies suggest that let-7 is a tumor suppressor, as let-7 directly regulates and suppresses the RAS and HMGA2 oncogenes through their $3^{\prime}$-UTR
(Johnson et al. 2005, Akao et al. 2006, Lee \& Dutta 2007). Moreover, a reduced let-7 level was also reported to correlate with elevated RAS expression in lung squamous carcinoma (Johnson et al. 2005). Apart from the role as a tumor suppressor, the involvement of let-7 in the cell proliferation pathway in human cells has been reported recently (Johnson et al. 2007). Let-7a, one of the let- $7 \mathrm{miR}$ members, was found to modulate the interleukin-6-dependent STAT-3 survival signaling in human malignant cholangiocytes by targeting the tumor suppressor gene NF2 (Meng et al. $2007 a, b)$. By computer-based sequence analysis, the potential recognition sequence of let-7a was found on the $3^{\prime}$-UTR of caspase- 3 but not on the other caspase members. Moreover, down-regulation of caspase-3, but not the other caspases, such as caspase- 8 or -9 , was observed in cells upon ectopic let-7a expression. By targeting caspase-3, a well-known effector caspase in apoptosis, let-7a was subsequently found to suppress the drug-induced apoptosis in A431 cells and HepG2, cells lines of two different tissue origins. Further confirmation of the role of caspase- 3 in let-7a regulation of apoptosis is provided by the observations that the caspase- 3 inhibitor attenuated the enhancement effect of let-7a knockdown on doxorubicininduced apoptosis in HepG2, A431, and A10A cells and that transfection with anti-let-7a inhibitor did not have effect on doxorubicin-induced apoptosis in MCF-7 cells, which do not express the endogenous caspase-3. All these results draw the conclusion that let-7a regulation of apoptosis is mediated by caspase- 3 (Tsang \& Kwok 2008). 


\section{miR-15a and miR-16-1}

Using bioinformatics tools, our group found that the miR-15a and miR-16-1 targeted the BCL2 mRNA sequence (Cimmino et al. 2005). Bcl-2 is a central player in the genetic program of eukaryotic cells, favoring survival by inhibiting cell death (Cory \& Adams 2002). Overexpression of the BCL2 protein has been reported in many types of human cancers, including leukemia, lymphomas, and carcinomas (Sanchez-Beato et al. 2003). In follicular lymphomas and in a fraction of diffuse B-cell lymphomas, the $B C L 2$ gene expression is deregulated through a translocation mechanism $\mathrm{t}(14 ; 18)(\mathrm{q} 32 ; \mathrm{q} 21)$, which places the gene under the control of immunoglobulin heavy chain enhancers (Tsujimoto et al. 1984, 1985). The fact that the BCL2 gene is overexpressed in $65-70 \%$ of B-cell chronic lymphocytic leukemias (CLLs) and that deletions or down-regulation of the miR-15a and miR-16-1 cluster have been reported in the same proportion of CLL samples led us to hypothesize that miR-15a and miR-16-1 could be responsible for the increased levels of Bcl-2 in CLL (Cimmino et al. 2005). Indeed, our data showed that miR-15a and miR-16-1 expressions are inversely correlated with Bcl-2 expression in CLL samples and that both miRs negatively regulate $\mathrm{Bcl}-2$ at a posttranscriptional level. Bcl-2 repression by these miRs induced apoptosis in a leukemic cell line model. In MEG-01 cells transfected with the wild-type miR-15/ 16 , we observed an increased rate of apoptosis mediated by cleavage of pro-caspase- 9 andpi tlsb of poly (ADP-ribose) polymerase, indicating that the reduction in BCL2 protein levels caused by miRs is sufficient to initiate the apoptotic process (Cimmino et al. 2005).

Given that Bcl-2 is overexpressed in the majority of CLL malignant lymphocytes and no genetic alteration can explain this aberration, control of Bcl-2 expression by the miR-15/16 cluster can be considered as one of the main molecular mechanisms of this phenomenon. To further shed light on the tumor suppressor action of the miR-15a and miR-16-1 cluster, we analyzed the effects of both miRs on the transcriptome and proteome in CLL cells (Calin et al. 2008).

Ectopic expression of miR-15a and miR-16-1 led to the up-regulation of 265 genes and down-regulation of 3307 genes, among them the myeloid cell leukemia sequence $1(M C L-1)$ anti-apoptotic gene and other predicted targets of miR-15 and miR-16. Interestingly, $\sim 20 \%$ of the down-regulated genes had AU-rich elements (AREs), which could further support the finding that ARE-mediated instability is implicated in the regulation of gene expression by miR-16-1 (Jing et al. 2005). Analysis of the proteomic changes after overexpression of the miR-15a and miR-16-1 cluster revealed 27 different proteins that exhibited at least fourfold changes with respect to the control group. Intriguingly, the proteins BCL2 and Wilms tumor 1, a confirmed and predicted target respectively, were among the proteins with prominent changes. Other proteins found are involved in cell growth, the cell cycle, oncogenesis, tumor suppression, and antiapoptosis (Jing et al. 2005).

The tumor suppressor function of miR-15a/16-1 has also been addressed in vivo. In nude mice, ectopic expression of miR-15a/16-1 was found to cause dramatic suppression of tumorigenicity of MEG-01 leukemic cells exhibiting a loss of endogenous expression of miR-15a/16-1 (Calin et al. 2008). This observation confirms that miR-15a and miR-16-1 genes are tumor suppressors and are highly effective in preventing the growth of leukemic xenografts. The miR-15a/16-1 cluster targeting of BCL2 at the post-transcriptional level implies that miR genes play an important role in regulating apoptosis. Our data show that in cancer cells lacking these miRs, restoration of miR-15a and miR-16-1 triggers apoptosis and suppresses tumorigenicity (Cimmino et al. 2005). Therefore, it is possible that perturbation of the expression of oncosuppressor miR genes, such as miR-15a and miR-16-1, may lead to tumorigenesis.

\section{miR-21}

miR-21 is the most up-regulated miR across many cancer types (Volinia et al. 2006, Krichevsky \& Gabriely 2009). Its implication as an anti-apoptotic factor was first reported in human glioblastoma cells where its down-regulation increased apoptotic cell death (Chan et al. 2005) and in a mouse model (Si et al. 2007). miR-21 has been identified as a potential regulator of the phosphatase and tensin homolog (PTEN) in hepatocellular carcinoma (HCC; Meng et al. 2007a,b). $P T E N$ is a tumor suppressor gene, which negatively regulates cell proliferation and survival. Impairment of PTEN regulation is thought to play a role in oncogenic transformation (Keniry \& Parsons 2008). Inhibition of miR-21 was shown to increase PTEN expression in vitro, determining decreased cells proliferation, migration, and invasion. On the other hand, overexpression of miR-21 produced the opposite effect, supporting a role for miR-21 in regulating proliferation and tumorigenesis. The decreased PTEN expression was accompanied by the induction of constitutive phosphorylation of the focal adhesion 
kinase (FAK). FAK is a major target of PTEN, which is involved in cell cycle progression, cell survival, and migration (Park et al. 2002, Gautam et al. 2003). The opposite effect was seen upon inhibition of miR-21 in HCC cells. Furthermore, the regulation of PTEN by miR-21 was shown to increase expression of two matrix metallopeptidase (MMP)-9 and MMP-2, which are involved in invasion (Meng et al. 2007a,b) through FAK dephosphorylation in normal hepatocyte cells. Dissimilarly in breast cancer, Frankel et al. (2008) showed that overexpression or inhibition of miR-21 caused only subtle changes in PTEN expression, suggesting, as for other miRs, that functional targets of miR-21 may differ in different cell/tissue types.

miR-21 has been demonstrated to regulate the programmed cell death 4 gene (PDCD4; Lu et al. 2008). PDCD4 is a tumor suppressor protein that is overexpressed during apoptosis (Lankat-Buttgereit \& Göke 2009) and downregulated in human cancers. It has been shown to inhibit promoter-induced neoplastic transformation (Cmarik et al. 1999), tumor promotion, and progression (Jansen et al. 2005). The regulation of PDCD 4 by miR-21 is mediated by interaction at a miR-21 target site within the PDCD4 3'-UTR. This interaction negatively regulates PDCD4, influencing invasion and metastatic potentials of neoplastic cell (Asangani et al. 2008).

Similarly, a translational regulation of PDCD4 by miR-21 has been demonstrated in MCF-7 breast cancer cells (Frankel et al. 2008), in embryonic kidney cells HEK293T, and in a mouse epidermal cell system (Lu et al. 2008). The authors also demonstrated that overexpression of miR-21 increased the colony formation in MCF-7 cells, indicating a role in anchorage-independent transformation in these cells, which supports what had been seen in colorectal cancer (Asangani et al. 2008).

Taken together, these data strongly indicate the regulation of PDCD4 by miR-21, which appears to play a role in invasion and metastasis in both colorectal and breast cancers.

Since miR-21 is overexpressed in colon and breast cancers (Iorio et al. 2005, Asangani et al. 2008), deregulation of miR-21 may provide a mechanism for cancer initiation and progression in colorectal and breast carcinoma through its regulation of PDCD4.

Recently, miR-21 has been reported to target important tumor suppressor genes including the serpin peptidase inhibitor, clade B (ovalbumin), member 5 (SERPINB5/maspin; Zhu et al. 2008). Members of the human serpin family regulate a diverse array of serine and cysteine proteinases associated with essential biological processes such as fibrinolysis, coagulation, inflammation, cell mobility, cellular differentiation, and apoptosis. Most serpins are secreted and attain physiological concentrations in the blood and extracellular fluids. However, a subset of the serpin superfamily, the ov-serpins, also resides intracellularly (Silverman et al. 2001). Different groups have demonstrated that maspin is involved in sensitizing cells to apoptosis (Tahmatzopoulos et al. 2005, McKenzie et al. 2008) by targeting AKT.

Hence, the oncogenic potential of miR-21 lies in its ability to regulate multiple cancer-associated pathways, probably via multiple cellular targets, which may partially explain its frequent up-regulation in cancer.

A recent study shows that miR-21 (Singh et al. 2008), the levels of which increase following the induction of mouse ES cell differentiation, has potential binding sites in the $3^{\prime}$-UTRs of the mRNAs that encode for Nanog, SOX2, and possibly OCT4. These are key proteins that are involved in ES cell self-renewal (Houbaviy et al. 2003). Interestingly, the transcription of miR-21 itself is regulated in ES cells by a transcriptional repressor called the RE1-silencing transcription factor, which directly interacts with cis elements upstream of the miR-21 gene (Singh et al. 2008).

\section{miR-29}

The miR-29 subfamily contains three paralogs: miR-29a, b, and c, which map at the common fragile site FRA7 (Calin et al. 2004). miR-29a is constitutively expressed in all phases of the cell cycle, miR-29b is expressed at low levels except in mitotic cells, and miR-29c is not detectable (Hwang et al. 2007).

miR-29b, which is down-regulated in lung cancer and in CLL (Calin et al. 2005, Yanaihara et al. 2006), has been recently reported to target the MCL-1 in cholangiocarcinoma cells (Mott et al. 2007). Mcl-1 is an anti-apoptotic member of the BCL2 family of proteins, which binds to pro-apoptotic members Bim and Bid preventing TRAIL-induced apoptosis (Chen et al. 2005). The TRAIL-signaling pathway involves the binding of TRAIL ligand to cell surface DR4 and 5 (Degterev et al. 2003, Johnstone et al. 2008). Upon binding, the receptor trimerizes (Wang \& El-Deiry 2003), recruits the adaptor protein FADD, and initiates the caspase cascade, which results in apoptosis (Chinnaiyan et al. 1995). The TRAIL-signaling pathway has been shown to induce apoptosis in a number of transformed cell types both in vitro and in vivo (Schaefer et al. 2007). However, we found that some tumor cells display a TRAIL-resistant phenotype 
(Garofalo et al. 2008). Overexpression of Mcl-1 is common in cancers such as cholangiocarcinoma, where its expression renders cells resistant to TRAILmediated apoptosis. Silencing of this protein has been shown to sensitize cholangiocarcinoma cells to TRAIL (Taniai et al. 2004). Mott et al. (2007) showed that the expression of miR-29 was inversely related to Mcl-1 expression, also demonstrating the ability of miR-29 to sensitize cells to TRAIL-mediated apoptosis.

Enforced expression of miR-29b renders tumor cells more sensitive to apoptosis-inducing activity of TRAIL, suggesting that the miR-29b/MCL-1 connection is functionally important and could be exploited for cancer therapy.

\section{miR-34}

The miR-34 family comprises three processed miRs that are encoded by two different genes: miR-34a is encoded by its own transcript on the short arm of chromosome 1 (1p36), whereas miR-34b and miR-34c share a common primary transcript on the long arm of chromosome 11 (11q23) (Hermeking 2009). The members of this miR family share a high similarity, suggesting that they may share the same targets (Chang et al. 2007). Different groups, independently, identified miR-34 as a target for p53 (Bommer et al. 2007, Chang et al. 2007, Corney et al. 2007, He et al. 2007, Raver-Shapira et al. 2007, Tarasov et al. 2007). Using a p53-inducible system, they reported that the miR-34 family of miRs is directly regulated by $\mathrm{p} 53$, and that miR-34 mediates growth arrest in multiple cell lines via direct 3 -UTR regulation of cell cycle regulatory factors, such as cyclin E2 (CCNE2), cyclin-dependent kinase 4 (CDK4), and the hepatocyte growth factor receptor (c-Met). Ectopic expression of miR-34 also resulted in a reduction of phospho-Rb, supporting the hypothesis that miR-34 regulates $\mathrm{CDK} 4$ and CCNE2. Furthermore, miR-34a was shown to directly target E2F3. Ectopic expression of miR-34 caused arrest in the $G_{1}$ phase of the cell cycle and induced cellular senescence in primary human fibroblasts (Bommer et al. 2007, He et al. 2007). In addition, $\mathrm{miR}-34 \mathrm{~b} / \mathrm{c}$ inhibited proliferation and colony formation in soft agar (Corney et al. 2007). Welch et al. (2007) reported that miR-34a induces apoptosis when reintroduced into the neuroblastoma cell lines that show decreased expression of miR-34a. Chang et al. (2007) showed that miR-34a-induced apoptosis is at least in part dependent on the presence of wild-type p53, indicating that miR-34a may feed back to p53. This observation was confirmed by Yamakuchi et al.
(2008) and linked to the targeting of the silent information regulator (SIRT1) mRNA by miR-34a. SIRT1 is an NAD-dependent deacetylase, which inhibits several pro-apoptotic proteins in response to oxidative and genotoxic stress (Longo \& Kennedy 2006, Brooks \& Gu 2009). miR-34a inhibition of SIRT1 increases p53 acetylation on lysine 382 with a subsequent increased transcriptional activity of p53, which determines the induction of p21 and PUMA, which regulate cell cycle and apoptosis respectively. Furthermore, miR-34 leads to apoptosis in cells where the p53 is present (Yamakuchi et al. 2008). These results could lead to a possible scenario where the induction of miR-34 genes allows p53 to regulate the expression of a large number of proteins, even after their transcripts have already been synthesized. This type of regulation may be advantageous in situations of cellular stress, as it does not require the translation of additional effector proteins that would presumably take too long to allow time for repair (Hermeking 2009). In addition, targeting of p53-induced mRNAs by miR-34 may contribute to the fine tuning of the p53 response and prevent an uncontrolled, irreversible response to p53 activation (Cohen et al. 2006).

\section{miR-106b-25/107-92 clusters}

The miR-106b-25 cluster is composed of the highly conserved miR-106b, miR-93, and miR-25, which are overexpressed in different types of cancer, including gastric, prostate, pancreatic neuroendocrine tumors, neuroblastoma, and multiple myeloma (Ambs et al. 2008, Petrocca et al. 2008, Kan et al. 2009, Li et al. 2009). These miRs are located in a 515 bp region at chromosome 7q22, in the intron 13 of their host gene $M C M 7$, where they are cotranscribed in the context of MCM7 primary transcript (Petrocca et al. 2008). Amplification of this region has been reported in several studies in gastric cancer (Peng et al. 2003, Weiss et al. 2004, Takada et al. 2005), and MCM7 overexpression is an unfavorable indicator in prostate and endometrial cancers ( $\mathrm{Li}$ et al. 2005, Laitinen et al. 2008). This raises the possibility that MCM7 oncogenic properties could be linked, at least in part, to the hosted miRs. MCM7 is induced by E2F1, a transcription factor that controls the $\mathrm{G}_{1}-\mathrm{S}$ transition activating a variety of genes involved in DNA replication, and belongs to a family of specialized proteins that license chromosomal DNA to undergo replication once, and not more than once, at each cell cycle. It has been proposed that overexpression of MCM7 may allow rereplication, thereby causing 
aneuploidy. However, because $M C M 7$ mRNA and the intronic miR-106b-25 cluster derive from the same transcript, it is conceivable that MCM7 and miR106b-25 cooperate in exerting their oncogenic function through different complementary mechanisms. Because $M C M 7$ mRNA and preliminary miR-106b-25 are cotranscribed, E2F1 regulates the expression of both (Petrocca et al. 2008). In fact, E2F1 increases the expression of MCM7 and miR106b-25 precursors with identical kinetics, whereas E2F1 silencing by RNA interference parallels miR106b-25 precursor down-regulation. Although the possibility of a miR-106b-25-independent promoter cannot be excluded, there are not known E2F1binding sites up to -5000 bp from the miR-106b-25 locus, whereas MCM7 mRNA and miR-106b-25 precursor levels perfectly correlate in primary gastric tumors and normal mucosa. Therefore, at least in the case of E2F1-dependent regulation, MCM7 drives miR-106b-25 cluster expression. It is very reasonable that other MCM7 transcriptional regulators, such as MYC, MYCN, and AIB-1, can also activate this cluster in specific contexts. For example, we observed MYC-dependent regulation of miR-106b-25, whereas MYCN, an oncogene frequently amplified in neuroblastoma, may cause the reported elevation of miR$106 \mathrm{~b}-25$ in these tumors. The picture becomes even more complex as mature miR-106b and miR-93 directly regulate $\mathrm{E} 2 \mathrm{~F} 1$ expression by interacting with highly conserved binding sites on its $3^{\prime}$ untranslated region. The miR-17-92 cluster is a prototypical example of a polycistronic miR gene. In the human genome, the miR-17-92 cluster encodes six miRs (miR-17, miR-18a, miR-19a, miR-20a, miR19b-1, and miR-92-1), which are tightly grouped within an $800 \mathrm{bp}$ region of human chromosome 13 . Both the sequences of these mature miRs and their organization are highly conserved in all vertebrates. The human miR-17-92 cluster is located in the third intron of a $7 \mathrm{~kb}$ primary transcript known as C13orf 25 (Ota et al. 2004), and also regulates E2F1 expression through the same sites (Dews et al. 2006). This mechanism establishes a negative feedback loop between miR-106b-25/miR-17-92 and E2F1 that may work as a sensor to control E2F1 protein levels, providing cancer cells a way to escape E2F1-induced apoptosis. In fact, as with most oncogenes, overexpression of E2F1 above a critical threshold is perceived as an apoptotic signal. The functional implications of miR-106b-25 overexpression in gastric cancer are tightly linked with the transforming growth factor $\beta$ (TGF $\beta$ ) tumor suppressor pathway. In fact, these miRs silence two main downstream effectors of TGF $\beta$ signaling: the cell cycle inhibitor CDKN1A (p21) and the pro-apoptotic gene BCL2L11 (BIM) (Petrocca et al. 2008). Whereas miR-106b and miR-93 suppress p21 expression, which is required for TGF $\beta$-induced cell cycle arrest, miR-25 silences BIM expression, which is essential for TGF $\beta$ dependent apoptosis. Similarly, miR-17-5p and miR20a repress p21 expression, whereas miR-92 inhibits BIM expression, suggesting that miR-106b-25 and miR-17-92 cooperate in inactivating the TGF $\beta$ pathway. It is of note that the physiological role of these miRs emerges exclusively in the context of active TGF $\beta$ signaling: in fact, their silencing does not visibly alter the proliferation and the survival of gastric cancer cells in the absence of TGF $\beta$. Nonetheless, miR-106b-25/miR-17-92 targets occupy critical nodes at the intersection between the TGF $\beta$ pathway and the MYC network. Whereas the TGF $\beta$ pathway suppresses proliferation by down-regulating MYC and inducing p21 and other CDK inhibitors, MYC impairs the TGF $\beta$ pathway mainly by inhibiting p21 transcription. A fine balance between these pathways is crucial to maintain the proper control of cell proliferation and apoptosis. However, in normal cells, MYC is programed to activate BIM and trigger apoptosis as a safeguard mechanism, if TGF $\beta$ control should fail (Egle et al. 2004). The role of BIM in mediating miR-dependent apoptosis is supported by recent publications showing extensive apoptosis in the pre-B-cell compartment in B-cellspecific Dicer knockout (Koralov et al. 2008) and constitutive miR-17-92 knockout mice (Ventura et al. 2008) and expansion of the lymphocytic compartment in B-cell-specific miR-17-92 transgenic mice (Xiao et al. 2008). In these models, the observed phenotypes were associated with alterations in apoptosis and BIM expression.

That miR-106b-25 and miR-17-92 physiologically control apoptosis is supported by the fact that miR-1792/miR-106b-25 double knockout mice exhibit a much more severe phenotype, characterized by prenatal lethality and extensive apoptosis in the liver and in other organs, compared with miR-17-92 single knockout mice (Ventura et al. 2008).

\section{miRs-221/222}

miR-221 and miR-222 genes are clustered on chromosome Xp11.3 (Ciafre et al. 2005). They have been reported to be significantly up-regulated in primary glioblastomas, in papillary thyroid carcinoma, and in prostate cancer (Ciafre et al. 2005, Galardi et al. 2007, Visone et al. 2007). 
Recently, our group (Garofalo et al. 2008) has identified miR-221 and miR-222 as regulators of TRAIL sensitivity in NSCLC. TRAIL-resistant (CALU-1) and TRAIL-sensitive (H460) cell lines were identified; differences in sensitivity to TRAIL were not related to differences in endogenous receptor levels, as receptor levels were demonstrated to be comparable in both cell lines. miR analysis indicated differential expression of seven miRs in TRAILresistant cells compared to TRAIL-sensitive H460 cells. Overexpression of two of these miRs, miR-221 and miR-222, in TRAIL-sensitive cells increased resistance to TRAIL-induced cell death by $\sim 40 \%$ and reduced activation of caspase- 3 and -8 . By contrast, inhibition of these miRs in TRAIL-resistant cells resulted in a TRAIL-sensitive phenotype, indicating a role in determining cell sensitivity to TRAIL. Putative targets, the proto-oncogene Kit, and tumor suppressor p27kip1 (Felli et al. 2005, Galardi et al. 2007), both of which play important roles in the cell cycle and its regulation, were shown to be downregulated in cells exhibiting resistance to TRAIL. In vitro inhibition and overexpression of miR-221 and miR-222 modulated expression of both Kit and p27kip1, strengthening evidence that these genes are targets. Silencing of p27kip1 increased cell resistance to TRAIL, implicating a role for this protein in maintaining sensitivity to TRAIL. These data strongly point to a role for miR-221 and miR-222 in determining cellular sensitivity to TRAIL-induced apoptosis in NSCLC, through the regulation of key proteins Kit and p27kip1. Interestingly, a recent study has demonstrated that negative regulation of p27kip1 by miR-221 and miR-222 in breast cancer cells conferred resistance to the chemotherapeutic drug tamoxifen (Miller et al. 2008), indicating a common role for these miRs in different cancers.

\section{Conclusion}

During the course of cancer development, a normal cell progresses towards malignancy by acquiring defects in the regulatory pathways that control normal cell proliferation and homeostasis. When these mechanisms fail, one or more mutations can become stable and interfere with cell cycle regulation and with repairing processes, thus causing the cell to accumulate more and more mutations. Over the past decades, our efforts were focused on understanding the roles of protein-coding genes in cancer. Recently, it has become quite clear that a novel class of non-coding genes, the miRs, regulate a diverse set of cellular processes from immune function to hematopoietic lineage commitment, to embryonic development, to cell cycle regulation and apoptosis, supporting the idea that some synergism between several deregulated miRs and their protein-coding counterparts facilitates a favorable environment for cancer formation. The evasion of apoptosis underlies tumorigenesis and represents a major obstacle to successful therapy. Therefore, effort in the characterization of miR targets and function is imperative to improve our understanding of the role of miRs in tumorigenesis and facilitates the design of appropriate therapies targeting this novel group of molecules.

\section{Declaration of interest}

The authors declare that there is no conflict of interest that could be perceived as prejudicing the impartiality of the research reported.

\section{Funding}

This work was supported by the Associazione Italiana per la Ricerca sul Cancro AIRC (A Vecchione).

\section{Acknowledgements}

Figure 1 was made using PB tool software. The authors wish to thank Dr Dorothee Wernicke for critical reading of the manuscript.

\section{References}

Akao Y, Nakagawa Y \& Naoe T 2006 Let-7 microRNA functions as a potential growth suppressor in human colon cancer cells. Biological \& Pharmaceutical Bulletin 29 903-906.

Ambs S, Prueitt RL, Yi M, Hudson RS, Howe TM, Petrocca F, Wallace TA, Liu CG, Volinia S, Calin GA et al. 2008 Genomic profiling of microRNA and messenger RNA reveals deregulated microRNA expression in prostate cancer. Cancer Research 68 6162-6170.

Asangani IA, Rasheed SA, Nikolova DA, Leupold JH, Colburn NH, Post S \& Allgayer H 2008 MicroRNA-21 (miR-21) post-transcriptionally downregulates tumor suppressor Pdcd4 and stimulates invasion, intravasation and metastasis in colorectal cancer. Oncogene 27 2128-2136.

Ashkenazi A 2002 Targeting death and decoy receptors of the tumor-necrosis factor superfamily. Nature Reviews. Cancer 2 420-430.

Boldin MP, Varfolomeev EE, Pancer Z, Mett IL, Camonis JH \& Wallach D 1995 A novel protein that interacts with the death domain of Fas/APO1 contains a sequence motif related to the death domain. Journal of Biological Chemistry 270 7795-7798. 
Bommer GT, Gerin I, Feng Y, Kaczorowski AJ, Kuick R, Love RE, Zhai Y, Giordano TJ, Qin ZS, Moore BB et al. 2007 p53-Mediated activation of miRNA34 candidate tumor-suppressor genes. Current Biology 17 1298-1307.

Brennecke J, Hipfner DR, Stark A, Russell RB \& Cohen SM 2003 Bantam encodes a developmentally regulated microRNA that controls cell proliferation and regulates the proapoptotic gene hid in Drosophila. Cell 113 25-36.

Brooks CL \& Gu W 2009 How does SIRT1 affect metabolism, senescence and cancer? Nature Reviews. Cancer 9 123-128.

Bush JA \& Li G 2003 The role of Bcl-2 family members in the progression of cutaneous melanoma. Clinical \& Experimental Metastasis 20 531-539.

Bushati N \& Cohen SM 2007 microRNA functions. Annual Review of Cell and Development Biology 23 175-205.

Cai X, Hagedorn C \& Cullen BR 2004 Human microRNAs are processed from capped, polyadenylated transcripts that can also function as mRNAs. RNA 10 1957-1966.

Calin GA, Sevignani C, Dumitru CD, Hyslop T, Noch E, Yendamuri S, Shimizu M, Rattan S, Bullrich F, Negrini M et al. 2004 Human microRNA genes are frequently located at fragile sites and genomic regions involved in cancers. PNAS 101 2999-3004.

Calin GA, Ferracin M, Cimmino A, Di Leva G, Simizu M, Wojcic SE, Iorio MV, Visone R, Sever NI, Fabbri M et al. 2005 A microRNA signature associated with prognosis and progression in chronic lymphocytic leukemia. New England Journal of Medicine 353 1793-1801.

Calin GA, Cimmino A, Fabbri M, Ferracin M, Wojcik SE, Shimizu M, Taccioli C, Zanesi N, Garzon R, Aqeilan RI et al. $2008 \mathrm{MiR}-15 \mathrm{a}$ and miR-16-1 cluster functions in human leukemia. PNAS 105 5166-5171.

Chan JA, Krichevsky AM \& Kosik KS 2005 MicroRNA-21 is an antiapototic factor in human glioblastoma cells. Cancer Research 65 6029-6033.

Chang TC, Wentzel EA, Kent OA, Ramachandran K, Mullendore M, Lee KH, Feldmann G, Yamakuchi M, Ferlito M, Lowenstein CJ et al. 2007 Transactivation of miR-34a by p53 broadly influences gene expression and promotes apoptosis. Molecular Cell 26 745-752.

Chen L, Willis SN, Wei A, Smith BJ, Fletcher JI, Hinds MG, Colman PM, Day CL, Adams JM \& Huang DC 2005 Differential targeting of prosurvival Bcl-2 proteins by their BH3-only ligands allows complementary apoptotic function. Molecular Cell 17 393-403.

Chen JF, Mandel EM, Thomson JM, Wu Q, Callis TE, Hammond SM, Conlon FL \& Wang DZ 2006 The role of microRNA-1 and microRNA-133 in skeletal muscle proliferation and differentiation. Nature Genetics $\mathbf{3 8}$ 228-233.

Chendrimada TP, Gregory RI, Kumaraswamy E, Norman J, Cooch N, Nishikura K \& Shiekhattar R 2005 TRBP recruits the Dicer complex to Ago 2 for microRNA processing and gene silencing. Nature 436 740-744.
Chinnaiyan AM, O’Rourke K, Tewari M \& Dixit VM 1995 FADD, a novel death domain-containing protein, interacts with the death domain of Fas and initiates apoptosis. Cell 81 505-512.

Ciafre SA, Galardi S, Mangiola A, Ferracin M, Liu CG, Sabatino G, Negrini M, Maira G, Croce CM \& Farace MG 2005 Extensive modulation of a set of microRNAs in primary glioblastoma. Biochemical and Biophysical Research Communications 334 1351-1358.

Cimmino A, Calin GA, Fabbri M, Iorio MV, Ferracin M, Shimizu M, Wojcik SE, Aqeilan RI, Zupo S, Dono M et al. $2005 \mathrm{miR}-15$ and miR-16 induce apoptosis by targeting BCL2. PNAS 102 13944-13949.

Cmarik JL, Min H, Hegamyer G, Zhan S, Kulesz-Martin M, Yoshinaga H, Matsuhashi S \& Colburn NH 1999 Differentially expressed protein Pdcd4 inhibits tumor promoter induced neoplastic transformation. PNAS 96 14037-14042.

Cohen SM, Brennecke J \& Stark A 2006 Denoising feedback loops by thresholding - a new role for microRNAs. Genes and Development 20 2769-2772.

Corney DC, Flesken-Nikitin A, Godwin AK, Wang W \& Nikitin AY 2007 MicroRNA-34b and MicroRNA-34c are targets of p53 and cooperate in control of cell proliferation and adhesion-independent growth. Cancer Research 67 8433-8438.

Cory S \& Adams JM 2002 The Bcl2 family: regulators of the cellular life-or-death switch. Nature Reviews. Cancer 2 647-656.

Coultas L \& Strasser A 2003 The role of the Bcl-2 protein family in cancer. Seminars in Cancer Biology 13 115-123.

Debatin KM \& Krammer PH 2004 Death receptors in chemotherapy and cancer. Oncogene 23 2950-2966.

Degterev A, Boyce M \& Yuan J 2003 A decade of caspases. Oncogene 22 8543-8567.

Deveraux QL \& Reed JC 1999 IAP family proteins - suppressors of apoptosis. Genes and Development 13 239-252.

Dews M, Homayouni A, Yu D, Murphy D, Sevignani C, Wentzel E, Furth EE, Lee WM, Enders GH, Mendell JT et al. 2006 Augmentation of tumor angiogenesis by a Myc-activated microRNA cluster. Nature Genetics $\mathbf{3 8}$ 1060-1065.

Egle A, Harris AW, Bouillet P \& Cory S 2004 Bim is a suppressor of Myc-induced mouse B cell leukemia. PNAS 101 6164-6169.

Esquela-Kerscher A \& Slack FJ 2006 Oncomirs - microRNAs with a role in cancer. Nature Reviews. Cancer 6 259-269.

Felli N, Fontana L, Pelosi E, Botta R, Bonci D, Facchiano F, Liuzzi F, Lulli V, Morsilli O, Santoro S et al. 2005 MicroRNAs 221 and 222 inhibit normal erythropoiesis and erythroleukemic cell growth via kit receptor down-modulation. PNAS 102 18081-18086.

Frankel LB, Christoffersen NR, Jacobsen A, Lindow M, Krogh A \& Lund AH 2008 Programmed cell death 4 (PDCD4) is an important functional target of the microRNA miR-21 in breast cancer cells. Journal of Biological Chemistry 283 1026-1033. 
Fulda S \& Debatin KM 2006 Extrinsic versus intrinsic apoptosis pathways in anticancer chemotherapy. Oncogene 25 4798-4811.

Galardi S, Mercatelli N, Giorda E, Massalini S, Frajese GV, Ciafrè SA \& Farace MG 2007 miR-221 and miR-222 expression affects the proliferation potential of human prostate carcinoma cell lines by targeting p27Kip1. Journal of Biological Chemistry 282 23716-23724.

Garofalo M, Quintavalle C, Di Leva G, Zanca C, Romano G, Taccioli C, Liu CG, Croce CM \& Condorelli G 2008 MicroRNA signatures of TRAIL resistance in human non-small cell lung cancer. Oncogene 27 3845-3855.

Gautam A, Li ZR \& Bepler G 2003 RRM1-induced metastasis suppression through PTEN-regulated pathways. Oncogene 22 2135-2142.

Hammond SM, Bernstein E, Beach D \& Hannon GJ 2000 An RNA-directed nuclease mediates post-trascriptional gene silencing in Drosophila cells. Nature 404 293-296.

Han J, Lee Y, Yeom KH, Kim YK, Jin H \& Kim VN 2004 The Drosha-DGCR8 complex in primary microRNA processing. Genes and Development 18 3016-3027.

He L, He X, Lim LP, de Stanchina E, Xuan Z, Liang Y, Xue W, Zebder L, Magnus J, Ridzon D et al. 2007 A microRNA component of the p53 tumour suppressor network. Nature 447 1130-1134.

Henry-Mowatt J, Dive C, Martinou JC \& James D 2004 Role of mitochondrial membrane permeabilization in apoptosis and cancer. Oncogene 23 2850-2860.

Hermeking H 2009 The miR-34 family in cancer and apoptosis. Cell Death and Differentiation online advance publication.

Hipfner DR, Weigmann K \& Cohen SM 2002 The bantam gene regulates Drosophila growth. Genetics $\mathbf{1 6 1}$ 1527-1537.

Houbaviy HB, Murray MF \& Sharp PA 2003 Embryonic stem cell-specific microRNAs. Developmental Cell $\mathbf{5}$ 351-358.

Hwang HW, Wentzel EA \& Mendell JT 2007 A hexanucleotide element directs microRNA nuclear import. Science 315 97-100.

Igney FH \& Krammer PH 2002 Death and anti-death: tumour resistance to apoptosis. Nature Reviews. Cancer $\mathbf{2}$ 277-288.

Iorio MV, Ferracin M, Liu CG, Veronese A, Spizzo R, Sabbioni S, Magri E, Pedriali M, Fabbri M, Campiglio M et al. 2005 MicroRNA gene expression deregulation in human breast cancer. Cancer Research 65 7065-7070.

Jansen AP, Camalier CE \& Colburn NH 2005 Epidermal expression of the translation inhibitor programmed cell death 4 suppresses tumorigenesis. Cancer Research $\mathbf{6 5}$ 6034-6041.

Jing Q, Huang S, Guth S, Zarubin T, Motoyama A, Chen J, Di Padova F, Lin SC, Gram H \& Han J 2005 Involvement of microRNA in AU-rich element-mediated mRNA instability. Cell 120 623-634.
Johnson SM, Grosshans H, Shingara J, Byrom M, Jarvis R, Cheng A, Labourier E, Reinert KL, Brown D \& Slack FJ 2005 RAS is regulated by the let 7 microRNA family. Cell 120 635-647.

Johnson CD, Esquela-Kerscher A, Stefani G, Byrom M, Kelnar K, Ovcharenko D, Wilson M, Wang X, Shelton J, Shingara J et al. 2007 The let-7 microRNA represses cell proliferation pathways in human cells. Cancer Research 67 7713-7722.

Johnstone RW, Frew AJ \& Smyth MJ 2008 The TRAIL apoptotic pathway in cancer onset, progression and therapy. Nature Reviews. Cancer 8 782-798.

Kan T, Sato F, Ito T, Matsumura N, David S, Cheng Y, Agarwal R, Paun BC, Jin Z, Olaru AV et al. 2009 The miR-106b-25 polycistron, activated by genomic amplification, functions as an oncogene by suppressing p21 and Bim. Gastroenterology 136 1689-1700.

Karst AM \& Li G 2007 BH3-only proteins in tumorigenesis and malignant melanoma. Cellular and Molecular Life Sciences 64 318-330.

Keniry M \& Parsons R 2008 The role of PTEN signaling perturbations in cancer and in targeted therapy. Oncogene 41 5477-5485.

Ketting RF, Fischer SE, Bernstein E, Sijen T, Hannon GJ \& Plasterk RH 2001 Dicer functions in RNA interference and in synthesis of small RNA involved in the developmental in C. elegans. Genes and Development 15 2654-2659.

Kim VN 2005 MicroRNA biogenesis: coordinated cropping and dicing. Nature Reviews. Molecular Cell Biology 6 376-385.

Kischkel FC, Hellbardt S, Behrmann I, Germer M, Pawlita M, Krammer PH \& Peter ME 1995 Cytotoxicity-dependent APO-1 (Fas/CD95)-associated proteins form a deathinducing signaling complex (DISC) with the receptor. EMBO Journal 14 5579-5588.

Kloosterman WP \& Plasterk RH 2006 The diverse functions of microRNAs in animal development and disease.

Developmental Cell 11 441-450.

Koralov SB, Muljo SA, Galler GR, Krek A, Chakraborty T, Kanellopoulou C, Jensen K, Cobb BS, Merkenschlager M et al. 2008 Dicer ablation affects antibody diversity and cell survival in the B lymphocyte lineage. Cell 132 860-874.

Krichevsky AM \& Gabriely G 2009 miR-21: a small multifaceted RNA. Journal of Cellular and Molecular Medicine 13 39-53.

Laitinen S, Martikainen PM, Tolonen T, Isola J, Tammela TL \& Visakorpi T 2008 EZH2, Ki-67 and MCM7 are prognostic markers in prostatectomy treated patients. International Journal of Cancer 122 595-602.

Lankat-Buttgereit B \& Göke R 2009 The tumour suppressor Pdcd4: recent advances in the elucidation of function and regulation. Biology of the Cell 101 309-317.

Lavrik IN, Golks A \& Krammer PH 2005 Caspases: pharmacological manipulation of cell death. Journal of Clinical Investigation 115 2665-2672. 
Lee YS \& Dutta A 2007 The tumor suppressor microRNA let-7 represses the HMGA2 oncogene. Genes and Development 21 1025-1030.

Lee Y, Jeon K, Lee JT, Kim S \& Kim VN 2002 MicroRNA maturation: stepwise processing and subcellular localization. EMBO Journal 21 4663-4670.

Lee Y, Ahn C, Han J, Choi H, Kim J, Yim J, Lee J, Provost P, Radmark O, Kim S \& Kim VN 2003 The nuclear RNAse III Drosha initiates microRNA processing. Nature $\mathbf{4 2 5}$ 415-419.

Lee YS, Kim HK, Chung S, Kim KS \& Dutta A 2005 Depletion of human micro-RNA miR-125b reveals that it is critical for the proliferation of differentiated cells but not for the downregulation of putative targets during differentiation.

Journal of Biological Chemistry 280 16635-16641.

Lewis BP, Burge CB \& Bartel DP 2005 Conserved seed pairing, often flanked by adenosines, indicates that thousands of human genes are microRNA targets. Cell 120 15-20.

Li SS, Xue WC, Khoo US, Ngan HY, Chan KY, Tam IY, Chiu PM, Ip PP, Tam KF \& Cheung AN 2005 Replicative MCM7 protein as a proliferation marker in endometrial carcinoma: a tissue microarray and clinicopathological analysis. Histopathology 46 307-313.

Li Y, Tan W, Neo TW, Aung MO, Wasser S, Lim SG \& Tan TM 2009 Role of the miR-106b-25 microRNA cluster in hepatocellular carcinoma. Cancer Science $\mathbf{1 0 0}$ 1234-1242.

Longo VD \& Kennedy BK 2006 Sirtuins in aging and age-related disease. Cell 126 257-268.

Lu J, Getz G, Miska EA, Alvarez-Saavedra E, Lamb J, Peck D, Sweet-Cordero A, Ebert BL, Mak RH, Ferrando AA et al. 2005 MicroRNA expression profiles classify human cancers. Nature 435 834-838.

Lu Z, Liu M, Stribinskis V, Klinge CM, Ramos KS, Colburn NH \& Li Y 2008 MicroRNA-21 promotes cell transformation by targeting the programmed cell death 4 gene. Oncogene 31 4373-4379.

McKenzie S, Sakamoto S \& Kyprianou N 2008 Maspin modulates prostate cancer cell apoptotic and angiogenic response to hypoxia via targeting AKT. Oncogene 27 7171-7179.

Meng F, Henson R, Wehbe-Janek H, Smith H, Ueno Y \& Patel T 2007a The microRNA let-7a modulates interleukin-6-dependent STAT-3 survival signaling in malignant human cholangiocytes. Journal of Biological Chemistry 282 8256-8264.

Meng F, Henson R, Wehbe-Janek H, Ghoshal K, Jacob ST \& Patel T 2007b MicroRNA-21 regulates expression of the PTEN tumor suppressor gene in human hepatocellular cancer. Gastroenterology 133 647-658.

Miller TE, Ghoshal K, Ramaswamy B, Roy S, Datta J, Shapiro CL, Jacob S \& Majumder S 2008 MicroRNA-221/222 confers tamoxifen resistance in breast cancer by targeting p27Kip1. Journal of Biological Chemistry 283 29897-29903.
Mott JL, Kobayashi S, Bronk SF \& Gores GJ 2007 mir-29 regulates Mcl-1 protein expression and apoptosis. Oncogene 26 6133-6140.

Newman MA, Thomson JM \& Hammond SM 2008 Lin-28 interaction with the Let-7 precursor loop mediates regulated microRNA processing. RNA 14 1539-1549.

Ota A, Tagawa H, Karnan S, Tsuzuki S, Karpas A, Kira S, Yoshida Y \& Seto M 2004 Identification and characterization of a novel gene, C13orf25, as a target for 13q31-q32 amplification in malignant lymphoma. Cancer Research 64 3087-3095.

Park MJ, Kim MS, Park IC, Kang HS, Yoo H, Park SH, Rhee CH, Hong SI \& Lee SH 2002 PTEN suppresses hyaluronic acid-induced matrix metalloproteinase-9 expression in U87MG glioblastoma cells through focal adhesion kinase dephosphorylation. Cancer Research 62 6318-6322.

Pasquinelli AE, Reinhart BJ, Slack F, Martindale MQ, Kuroda MI, Maller B, Hayward DC, Ball EE, Degnan B, Müller P et al. 2000 Conservation of the sequence and temporal expression of let-7 heterochronic regulatory RNA. Nature 408 86-89.

Peng DF, Sugihara H, Mukaisho K, Tsubosa Y \& Hattori T 2003 Alterations of chromosomal copy number during progression of diffuse-type gastric carcinomas: metaphase- and array-based comparative genomic hybridization analyses of multiple samples from individual tumours. Journal of Pathology 201 439-450.

Petrocca F, Visone R, Onelli MR, Shah MH, Nicoloso MS, de Martino I, Iliopoulos D, Pilozzi E, Liu CG, Negrini M et al. 2008 E2F1-regulated microRNAs impair TGFbeta-dependent cell-cycle arrest and apoptosis in gastric cancer. Cancer Cell 13 272-286.

Raver-Shapira N, Marciano E, Meiri E, Spector Y, Rosenfeld N, Moskovits N, Bentwich Z \& Oren M 2007

Transcriptional activation of miR-34a contributes to p53mediated apoptosis. Molecular Cell 26 731-743.

Ravi R, Jain AJ, Schulick RD, Pham V, Prouser TS, Allen H, Mayer EG, Yu H, Pardoll DM, Ashkenazi A \& Bedi A 2004 Elimination of hepatic metastases of colon cancer cells via p53-independent cross-talk between irinotecan and Apo2 ligand/TRAIL. Cancer Research 64 9105-9114.

Reed JC 1998 Bcl-2 family proteins. Oncogene 17 3225-3236.

Reinhart BJ, Slack FJ, Basson M, Pasquinelli AE, Bettinger JC, Rougvie AE, Horvitz HR \& Ruvkun G 2000 The 21-nucleotide let-7 RNA regulates developmental timing in Caenorhabditis elegans. Nature 403 901-906.

Rieger J, Naumann U, Glaser T, Ashkenazi A \& Weller M 1998 APO2 ligand: a novel lethal weapon against malignant glioma? FEBS Letters 427 124-128.

Rowinsky EK 2005 Targeted induction of apoptosis in cancer management: the emerging role of tumor necrosis factor-related apoptosis-inducing ligand receptor activating agents. Journal of Clinical Oncology 23 9394-9407. 
Rybak A, Fuchs H, Smirnova L, Brandt C, Pohl EE, Nitsch R \& Wulczyn FG 2008 A feedback loop comprising lin-28 and let-7 controls pre-let-7 maturation during neural stemcell commitment. Nature Cell Biology 10 987-993.

Sanchez-Beato M, Sanchez-Aguilera A \& Piris MA 2003 Cell cycle deregulation in B-cell lymphomas. Blood 101 1220-1235.

Schaefer U, Voloshanenko O, Willen D \& Walczak H 2007 TRAIL: a multifunctional cytokine. Frontiers in Bioscience 12 3813-3824.

Schimmer AD 2004 Inhibitor of apoptosis proteins: translating basic knowledge into clinical practice. Cancer Research 64 7183-7190.

Si ML, Zhu S, Wu H, Lu Z, Wu F \& Mo YY 2007 miR21-mediated tumor growth. Oncogene 26 2799-2803.

Silverman GA, Bird PI, Carrell RW, Coughlin PB, Gettins PG, Irving JI, Lomas DA, Luke CJ, Moyer RW, Pemberton $\mathrm{J}$ et al. 2001 The serpins are an expanding superfamily of structurally similar but functionally diverse proteins. Evolution, mechanism of inhibition, novel functions, and a revised nomenclature. Journal of Biological Chemistry 276 33293-33296.

Singh SK, Kagalwala MN, Parker-Thornburg J, Adams H \& Majumder S 2008 REST maintains self renewal and pluripotency of embryonic stem cells. Nature $\mathbf{4 5 3}$ 223-227.

Srinivasula SM, Datta P, Fan XJ, Fernandes-Alnemri T, Huang Z \& Alnemri ES 2000 Molecular determinants of the caspase-promoting activity of Smac/DIABLO and its role in the death receptor pathway. Journal of Biological Chemistry 275 36152-36157.

Tahmatzopoulos A, Sheng S \& Kyprianou N 2005 Maspin sensitizes prostate cancer cells to doxazosin-induced apoptosis. Oncogene 24 5375-5383.

Takada H, Imoto I, Tsuda H, Sonoda I, Ichikura T, Mochizuki H, Okanoue T \& Inazawa J 2005 Screening of DNA copy-number aberrations in gastric cancer cell lines by array-based comparative genomic hybridization. Cancer Science 96 100-110.

Tang Y, Zheng J, Sun Y, Wu Z, Liu Z \& Huang G 2009 MicroRNA-1 regulates cardimomycyte apoptosis by targeting Bcl-2. International Heart Journal 50 377-387.

Taniai M, Grambihler A, Higuchi H, Werneburg N, Bronk SF, Farrugia DJ, Kaufmann SH \& Gores GJ 2004 Mcl-1 mediates tumor necrosis factor-related apoptosis-inducing ligand resistance in human cholangiocarcinoma cells. Cancer Research 64 3517-3524.

Tarasov V, Jung P, Verdoodt B, Lodygin D, Epanchintsev A, Menssen A, Meister G \& Hermeking H 2007 Differential regulation of microRNAs by $\mathrm{p} 53$ revealed by massively parallel sequencing: miR-34a is a p53 target that induces apoptosis and $\mathrm{G}_{1}$-arrest. Cell Cycle 6 1586-1593.

Tsang WP \& Kwok TT 2008 Let-7a microRNA suppresse therapeuthics-induced cancer cell death by targeting caspase-3. Apoptosis 13 1215-1222.

Tsujimoto Y, Yunis J, Onorato-Showe L, Erikson J, Nowell PC \& Croce CM 1984 Molecular cloning of the chromosomal breakpoint of B-cell lymphomas and leukemias with the $\mathrm{t}(11 ; 14)$ chromosome translocation. Science 224 1403-1406.

Tsujimoto Y, Cossman J, Jaffe E \& Croce CM 1985 Involvement of the bcl-2 gene in human follicular lymphoma. Science 228 1440-1443.

Ventura A, Young AG, Winslow MM, Lintault L, Meissner A, Erkeland SJ, Newman J, Bronson RT, Crowley D, Stone JR et al. 2008 Targeted deletion reveals essential and overlapping functions of the miR-17 through 92 family of miRNA clusters. Cell 132 875-886.

Visone R, Russo L, Pallante P, De Martino I, Ferraro A, Leone V, Borbone E, Petrocca F, Alder H, Croce CM et al. 2007 MicroRNAs (miR)-221 and miR-222, both overexpressed in human thyroid papillary carcinomas, regulate p27Kip1 protein levels and cell cycle. Endocrine-Related Cancer 14 791-798.

Viswanathan SR, Daley GQ \& Gregory RI 2008 Selective blockade of microRNA processing by Lin28. Science $\mathbf{3 2 0}$ 97-100.

Volinia S, Calin GA, Liu CG, Ambs S, Cimmino A, Petrocca F, Visone R, Iorio M, Roldo C, Ferracin M et al. 2006 A microRNA expression signature of human solid tumors defines cancer gene targets. PNAS 103 2257-2261.

Wang S \& El-Deiry WS 2003 TRAIL apoptosis induction by TNF; family death receptors. Oncogene 22 8628-8633.

Wang J, Chun HJ, Wong W, Spencer DM \& Lenardo MJ 2001 Caspase-10 is an initiator caspase in death receptor signaling. PNAS 98 13884-13888.

Weiss MM, Kuipers EJ, Postma C, Snijders AM, Pinkel D, Meuwissen SG, Albertson D \& Meijer GA 2004 Genomic alterations in primary gastric adenocarcinomas correlate with clinicopathological characteristics and survival. Cellular Oncology 26 307-317.

Welch C, Chen Y \& Stallings RL 2007 MicroRNA-34a functions as a potential tumor suppressor by inducing apoptosis in neuroblastoma cells. Oncogene $\mathbf{2 6}$ 5017-5022.

Xiao C, Srinivasan L, Calado DP, Patterson HC, Zhang B, Wang J, Henderson JM, Kutok JL \& Rajewsky K 2008 Lymphoproliferative disease and autoimmunity in mice with increased miR-17-92 expression in lymphocytes. Nature Immunology 9 405-414.

Xu P, Vernooy SY \& Hay BA 2003 The Drosophila microRNA mir-14 suppresses cell death and is required for normal fat metabolism. Current Biology 13 790-795.

Xu C, Lu Y, Pan Z, Chu W, Luo X, Lin H, Xiao J, Shan H, Wang Z \& Yang B 2007 The muscle-specific microRNAs miR-1 and miR-133 produce opposing effects on apoptosis by targeting HSP60, HSP70 and caspase-9 in cardiomyocytes. Journal of Cell Science 120 3045-3052.

Yamakuchi M, Ferlito M \& Lowenstein CJ 2008 miR-34a repression of SIRT1 regulates apoptosis. PNAS $\mathbf{1 0 5}$ 13421-13426.

Yanaihara N, Caplen N, Bowman E, Seike M, Kumanoto K, Yi M, Stephens RM, Okamoto A, Yokota J, Tanaka T 
et al. 2006 Unique microRNA molecular profiles in lung cancer diagnosis and prognosis. Cancer Cell 9 189-198.

Yi R, Qin Y, Macara IG \& Cullen BR 2003 Exportin-5 mediates the nuclear export of pre-microRNAs and short hairpin RNAs. Genes and Development 17 853-858.

Yu J, Vodyanik MA, Smuga-Otto K, AntosiewiczBourget J, Frane JL, Tian S, Nie J, Jonsdottir GA,
Ruotti V, Stewart R et al. 2007 Induced pluripotent stem cell lines derived from human somatic cells. Science 318 1917-1920.

Zhao Y, Samal E \& Srivastava D 2005 Serum response factor regulates a muscle-specific microRNA that targets Hand2 during cardiogenesis. Nature 436 214-220.

Zhu S, Wu H, Wu F, Nie D, Sheng S \& Mo YY 2008 MicroRNA-21 targets tumor suppressor genes in invasion and metastasis. Cell Research 18 350-359. 